\title{
Failures of the Discourse of Ethnicity: Turkey, Kurds, and the Emerging Iraq
}

\author{
MURAT SOMER* \\ Koç University, Istanbul, Turkey
}

This article analyzes the discursive-ideational barriers restricting regional cooperation by examining Turkey's relations with Iraqi Kurds from a critical, theoretical perspective in the context of Turkey's domestic reforms and its relations with the USA and the EU. It is argued that the ethnicity discourse undermines cooperation, insofar as it feeds the perception of rival groups with zero-sum interests. Presenting a simple model, the article argues that replacing the ethnicity discourse with alternative, post-ethnic discourses requires combining alternative discourses with policies that produce positivesum interests, coordination between groups, and opportunities for joint collective actions. Hence, state capacity to formulate and implement such policies is crucial. Predictions and policy implications are generated accordingly. First, further reconciliation of Turkey's domestic Kurdish conflict through democratic and administrative reforms, EU integration, and the promotion of national-identity models that are more flexible and more reflective of diversity will facilitate cooperation with Iraqi Kurds. Second, prosperity and democratic stability in Iraq will help achieve a lasting resolution in Turkey. Third, regional cooperation requires that domestic and external actors promote the positive-sum perception of Turkish and Kurdish interests. Fourth, research can help by developing linguistic-analytical categories that transcend the narrow discourse of ethnicity in favor of discourses that reflect multiple and compatible group belongings.

Keywords ethnicity discourse $\cdot$ ethnic identity and conflict • Turkey $\cdot$ Iraq $\cdot$ Kurds

$\Gamma$ THE CASE OF TURKEY, KURDS, AND THE EMERGING IRAQ demonstrates the discursive-ideational difficulties that states and nonstate actors face in building cooperative relations in a changing international context. In particular, it shows how the discourse of ethnicity undermines the adoption of policies facilitating cooperation, insofar as it takes the form of 'rival ethnic groups' or tends to be perceived as doing so. At the same time, a systematic reading of this case in light of theories of 
ethnic mobilization helps us to gain insights into the difficulties of promoting a 'post-ethnic' or 'post-nationalist' politics and discourse outside the purview of the EU and in an environment of limited state capacity and fierce political competition. Thus, an 'analytical narrative' of this case reveals the critical links between ideational variables, such as post-ethnic identity models, and material and institutional variables, such as economic interest, state capacity, and external institutional context. ${ }^{1}$

Hypothetically, as one of Iraq's major neighbors and as a democracy at the doorsteps of the EU, Turkey could make a major contribution to regional security and development by focusing on Iraq's reconstruction and reconfiguration as a stable democracy. However, from the perspective of dispassionate scholars and actors who are interested in regional peace and prosperity, the public discussions regarding Turkey's role in Iraq have so far been unduly narrow. Pending a detailed review of recent events in the next section, suffice it to say here that Turkey has been preoccupied with preventing Iraqi-Kurdish statehood or limiting Kurdish autonomy, Iraqi Kurds with avoiding Turkey's involvement, the USA with balancing the apparently conflicting interests of the two, and the EU with trying to form a common foreign policy. Although unlikely, there still is some risk of armed conflict between Turkey and Iraqi Kurds, which would also involve Iraqi-Turkmen groups. Efforts to transcend what appear to be 'ethnic redlines' on both sides and establish more cooperative relations based on common neighborly interests have so far had limited success.

Why have actors failed to focus on common long-term interests, such as regional cooperation and development, at least on a conceptual level? The answer has significant theoretical import and policy implications for both the present case and others. One way to approach this question would be through an examination of the state and non-state interests that are revealed by the behavior of the various actors. To differing degrees, most studies on Turkey and Kurds reflect this approach, which is consistent with the neorealist and neo-institutionalist paradigms in the field of international relations, particularly the former (Barkey, 2000; Robins, 2003; Gunter, 2004a). This approach treats group identities such as the Turkish and Kurdish group identities as more or less given, and focuses on variables such as military and political power and the political transaction costs of achieving cooperation, although the links between these variables and identities admittedly also 'need investigation' within the said paradigms (Goldstein \& Keohane, 1993: 8). An alternative approach, inspired by the constructivist paradigm in international relations, would disaggregate the group identities and examine how their specific constructions shape actors' perceptions of interest and the opportunities for cooperation (Ruggie, 1998). Constructivist studies, how-

\footnotetext{
${ }^{1}$ For analytical narratives, see Bates et al. (1998). For a critique and rebuttal, see American Political Science Review, 2000.
} 
ever, rarely attempt to explain why one particular identity construction prevails over another in a given context, and how actors who are interested in cooperation can promote alternative identity constructions.

The approach adopted in this article is to examine the interaction between the variables highlighted by both of the previously described approaches. On one hand, the article explores the extent to which the identity categories that actors use to describe and analyze their environment affect their perceptions of group interests and undermine or facilitate the possibilities for cooperation. In particular, the implications of the use of narrowly defined ethnic categories are examined. On the other hand, the article investigates why these rather than alternative identity categories often dominate actors' perceptions and behavior. In particular, the article examines the material and institutional barriers that alternative, post-ethnic discourses and identity projects face. It then develops a simple analytical model linking actors' dominant conceptions of their identities to material and institutional variables and generates policy implications for the Turkish case accordingly.

\section{Turkey and the War on Iraq}

From the beginning of the US-led campaign against Iraq, Turkey came under intense US pressure to join the campaign. The EU, which Turkey aims to join as a full member, failed to take a unified position toward the war, but at a minimum Turkey's entanglement in the war bore the risk of turning European public opinion against Turkish membership. Turkish military involvement in Iraq could have destabilized Turkey's relations with neighboring Iran and Syria, which might have perceived their interests as being threatened by such involvement. ${ }^{2}$ Most importantly for a struggling democracy, public opinion was overwhelmingly against the war. The reasons for this included the absence of a UN mandate for the war, disdain for overextended hegemonic power, suspicions about US intentions in the region, and pessimistic expectations regarding the war's implications for Turkey's economy.

All the same, the newly elected government of the Justice and Development Party (AKP) gave in to US pressure after a lengthy period of indecision, diplomatic efforts to persuade the Iraqi and US governments to seek a peaceful solution, consultations with the president and the military, and intense negotiations with the US government. ${ }^{3}$ However, on 1 March 2003, the parliament declined the government's motion to authorize the deployment

2 At the same time, Turkish authorities feared that Turkey's lack of involvement, especially in Northern Iraq, might encourage Iran and Syria to fill the gap.

${ }^{3}$ Yetkin (2004) offers a detailed and informed journalistic narrative. 
of US troops in Turkey and the sending of Turkish troops to Iraq by a margin of two votes. This was a major blow to US-Turkish relations on a level not seen since the rows over Cyprus in the 1960s; Turkey had been a major and consistent strategic partner for the USA, which in turn had supported Turkey in such important areas as its bid for EU membership and its financial needs during economic crises.

Understandably, the issue on which most commentators focus is why the parliament failed to endorse the government's motion in Turkey's parliamentary system, which had been government-dominated until the March decision (Robins, 2003). Apparently, many factors contributed to the outcome, including the new government's own indecision and inexperience, strategic mistakes by the USA, and the complex mixture of rivalry and cooperation between the moderate Islamic-conservative AKP and the country's secular establishment, both civil and military. ${ }^{4}$

However, this focus ignores the strong and vocal opposition to the war by the public, the president, the military, and members of the government itself. Thus, a more appropriate question than why the motion failed to pass is how it could garner as much support as it did and why the government unwillingly decided to support the US campaign in the first place. ${ }^{5}$

One can cite two main reasons. The easily explicable reason was US pressure. If Turkey lacked the power to prevent the war, it was thought, it was better to support the USA and remain a good ally than to disappoint the USA and lose the ability to have a say in Iraq's postwar reconfiguration. ${ }^{6}$ After intensive negotiations, the USA had also agreed to offer a generous package of financial compensation for the economic losses that Turkey's fragile economy would incur as a result of the war.

The more problematic reason, which is the focus of this article, was the belief that joining the coalition was the only way in which Turkey could minimize the potential negative consequences for Turkey's domestic Kurdish conflict (Barkey \& Fuller, 1997; Bruinessen, 1998; Yavuz \& Gunter, 2001). Lasting reconciliation in this conflict was far from complete, despite the positive impact of significant reforms that had been legislated during the prior two years but had yet to be adequately implemented (Kirişçi, 2004; Somer, 2004).

What were the feared consequences for the domestic Kurdish conflict? Turkey appears to have tried to avert two major consequences, from which

\footnotetext{
${ }^{4}$ Apparently, the US government seriously underestimated the potential autonomy of the Turkish parliament. When high-level US representatives such as Paul Wolfowitz and Marc Grossman visited Turkey and had meetings with a wide range of Turkish authorities, including chairs of political parties, they did not even bother to visit the head of the parliament (Yetkin, 2004: 99).

5 Technically, the motion was not even rejected: out of the 533 members of the parliament who were present in the session, 264 voted in favor, 250 against, and 19 abstained. Owing to the abstentions, the yes votes fell short of the absolute majority necessary to pass the motion.

${ }^{6}$ Apparently, some members of parliament wrongly thought that they could prevent the war, and this influenced their voting (Yetkin, 2004).
} 
secondary policy goals such as its opposition to Kurdish control of the oil-rich city of Kirkuk were derived. ${ }^{7}$ The first consequence was that the Kurdistan Workers Party (PKK), which fought a separatist war against Turkey between 1984 and 1999, would find a safe haven in Kurdishcontrolled northern Iraq. ${ }^{8}$ The second possible consequence was IraqiKurdish statehood or autonomy.

The PKK had proved to be a major threat to Turkish state security. Armed clashes with it, which were believed to have cost more than 30,000 lives, mostly ended when the movement's leader Abdullah Öcalan was captured with US assistance in Kenya and jailed for life in 1999. However, the PKK remained active politically and militarily in Turkey, Iraq, and other countries, including parts of Western Europe.

The reasons for the concern with Kurdish statehood are more complex and require more critical evaluation. A substantial portion of Turkish military and political leaders long suspected the USA - and Israel - of sympathizing with Iraqi-Kurdish statehood, ${ }^{9}$ and they apparently believed that Kurdish statehood would reignite Kurdish secessionism within Turkey. In terms of Goldstein \& Keohane's (1993: 10) conceptualization, this expectation fits the category of causal beliefs: 'cause-effect relationships which derive authority from shared consensus of recognized elites'. Causal beliefs are argued to change more easily and frequently than 'worldviews' and 'principled beliefs', which are intertwined with people's identities and normative beliefs. Can one therefore expect Turkish elites' beliefs regarding the consequences of Iraqi-Kurdish statehood for Turkey to change relatively easily?

Close scrutiny demonstrates that the beliefs underlying the concerns of Turkish elites are intertwined with identity-related beliefs. These beliefs, rather than ethnic identity itself, seem to cause policy-rigidity. These beliefs apparently draw on a number of presumptions regarding (Kurdish) ethnicity. The first three are that Kurdish identity is more or less monolithic across Turkey and northern Iraq; it is, at least as a propensity, the primary source of group identity for the Kurdish-speaking people; and ethnic identification is birth-given and involves little or no individual choice. Together, these beliefs lead to the expectation that the consolidation of the Kurdish identity via internationally recognized statehood would make Turkish and Iraqi Kurds identify with it more than alternative identities, such as religion, social class, and Turkish and Iraqi national identities.

Accordingly, one observer of Turkish foreign policy claimed that 'in Turkish security perceptions . . . northern Iraq and southeastern Turkey are

\footnotetext{
7 Another goal, which was partially instrumental to the Kurdish question, was the protection of IraqiTurkmen interests.

${ }^{8}$ The PKK has announced several times that it has renamed itself. To prevent confusion, I will refer to it as the PKK, the name by which the movement is most widely known.

${ }^{9}$ Özkan (2004) offers a detailed journalistic narrative of these suspicions.
} 
the geographic and ethno-cultural extensions of each other' (Çandar, 2004: 53). Alternatively, one may believe that significant cultural-political and regional differences exist between Turkish and Iraqi Kurds, and that people can have multiple and mixed conceptions of their identities, whereby ethnicity has to compete with other sources of belonging, such as national, supranational, and regional identities. In this case, there would be no reason to expect that Kurdishness would automatically or necessarily become the primary (social and political) identity among Turkish and Iraqi Kurds. Such a view does not reject the idea that ethnic identities are normally birth-given, and thus fixed at least through one's lifetime. But, it surmises that the social and political contents and significances of ethnic identities can shift over time and that individuals, who act as individuals or in groups, have some choice over determining their ethnicity's social-political significance whenever they have access to alternative identities. ${ }^{10}$

A fourth presumption appears to be that in the image of an accentuated Kurdish identity in the region, Turks would necessarily become the primary and the enemy - or, at least, rival - 'other'. The construction of national and other identities may necessarily involve the creation of new divisions between insiders and 'others'. As will be argued in more detail, however, the creation of enemy others does not automatically follow the creation of others. Even if Turks became the primary other for Kurds because of the geographical mixing and historical coexistence of the two, whether Turks would also become the enemy other would depend on the discursive, socioeconomic, and political developments following Kurdish statehood.

The fifth presumption appears to be that, if encouraged by the example of Iraqi-Kurdish statehood, Kurdish ethnopolitical mobilization would necessarily be more attractive for the majority of Turkish Kurds than alternative political movements based on cross-ethnic cleavages such as class, ideology, gender, and religion. Otherwise, there would be no reason to expect that Iraqi-Kurdish statehood would necessarily boost Kurdish-nationalist mobilization within Turkey. Finally, the sixth presumption appears to be that an Iraqi-Kurdish state or autonomous entity would necessarily support Kurdish secessionism in Turkey. According to this presumption, for the Kurdish citizens of an Iraqi-Kurdish state, attachment to Kurdish ethnicity or the desire to unite with their ethnic brethren would necessarily be more important than peace and cooperation with Turkey. Again, whether or not a hypothetical Kurdish state would make such a choice depends on a number of conditions to be critically evaluated.

Returning to events after the invasion of Iraq, in October 2003 the parliament authorized the deployment of Turkish troops to join the coalition forces in Iraq, in accordance with US demands. However, this prospect met with vocal Iraqi opposition, especially from Iraqi Kurds. They feared that Turkey

${ }^{10}$ For an able discussion, see Laitin (1998), especially Chapter 1. 
would use its military presence against Kurdish statehood. Iraqi Kurdish leaders' fervent declarations against Turkey's involvement accompanied anti-Turkish protests in northern Iraq. These statements and protests suggested that powerful ethnically defined fears prevailed among Iraqi Kurds also, despite a history of significant cooperation between them and the Turkish government during the 1990s. ${ }^{11}$ When it became apparent that the USA would abide by the Iraqis' will, the government repealed its offer to deploy troops. Turkish leaders complained that the US was favoring Iraqi Kurds, as opposed to the Iraqi Turkmen and Turkey, and stressed that Turkey would intervene militarily against any threats to its own territory. ${ }^{12}$ Quite often, Turkish policymakers also stated their support for the wellbeing of Iraqis of all ethnic stripes and their benign intentions toward Iraqi Kurds, and signaled a more flexible policy. ${ }^{13}$ However, these efforts failed to signal a major transformation of Turkey's priorities, and were anyhow undermined by what the Turkish and Iraqi-Kurdish parties perceived as provocative acts by each other.

\section{The Ontological and Practical Value of the Ethnicity Discourse}

Conflicts that seem to be 'ethnic' often include multiple layers of private and public identities and interests, most of which have nothing to do with ethnicity. Furthermore, the ethnic or national categories that are conveniently used to explain group conflicts do not exist independently of those conflicts; they are often created, or changed, as a result of such conflicts (Somer, 2001). Thus, it is often misleading to use these categories as 'analytical' or explanatory categories, even though they may be 'practical categories' that are highly valued by the actors themselves. Such usage implies that these categories are the causes rather than the effects of conflict (Brubaker, 1996; Kalyvas, 2003; Somer, 2004).

More importantly for the purposes here, the use of ethnicity as a discursiveanalytical category has important policy ramifications: supporting political elites capitalizing on ethnicity to increase their own power; international indifference to humanitarian catastrophes falsely portrayed as ancient ethnic conflicts; false perception of clashing interests between ordinary ethnic group members; etc. Unlike the claim in some otherwise insightful studies, the metaphor of rival ethnic groups is not just another metaphor simplifying reality, 'the price of maintaining consistency, order, and meaning in our lives

11 Turkish Daily News (2003a,b).

12 Turkish Daily News (2003c).

13 Gorvett, 2003; Ergan, 2003. 
... in a world of partial and uncertain truths' (Kuusisto, 1998: 603-620). For example, the ethnicity metaphor legitimized the outside world's long period of inaction during the war in Bosnia, although former Yugoslavia was not necessarily a country doomed to failure by a population divided into antagonistic ethnic groups (Somer, 2001, 2002). These metaphors are used by governments and other actors to shape reality in ways that justify certain actions and policies, and undermine others. Alternatively, a discourse that actors adopt as an unintended outcome of the political process can later restrict the choices available to those actors.

In the case of Turkey and Kurds, too, scholars often refer to Kurds and Turks as analytical categories. Gunter (2004a) writes, for example, that Kurds are 'the largest nation in the world without its own state', before proceeding to discuss, at length, the significant geographical, political, linguistic, tribal, and ideological divisions that exist between, and among, the Kurds living in Turkey, Iraq, Iran, and Syria, and the absence of the historical precedence of a Kurdish state. ${ }^{14}$ This treatment essentializes nationhood without explaining it, and strips it of any political content in favor of ethnicity. True, the concept of nation is undergoing change, being somewhat de-linked from the political notion of nation-state (Salih, 2004). However, such change toward 'postsovereign' nationalism is most visible within the framework of supranational projects such as European integration (Keating, 2004). Expecting it to happen outside this framework is a significant theoretical leap that needs to be substantiated.

Worse, observers occasionally resort to the ethnic-rivalry metaphor - for example, 'relations between Turks and Kurds are clouded by mutual suspicions rooted in repeated conflicts' (Schmitt, 2003). Such terminology gives the impression that Kurds and Turks are monolithic groups with historically clashing interests. Whether the reality matches this description is highly debatable. Like other ethnic groups or nations in the making, Kurds do not form a monolithic group, but feature a variety of intra-Kurdish differences, such as religious, tribal, social class, gender, and political and ideological differences; different political-institutional experiences, including those of national identity and citizenship, of the Iraqi, Persian, Turkish, and European Kurds; and different relations with transnational networks and, for recent Kurdish immigrants, with their host countries (Bruinessen, 1998; Yavuz \& Gunter, 2001; Natali, 2004). One notable result of such differences might have been that Turkish Kurds strongly opposed the US war on Iraq, while Iraqi Kurds' representatives actively supported it (Birand, 2003).

There are significant tribal, religious, linguistic, socio-economic, and political distinctions among Turkish Kurds. The Kurdish conflict in Turkey is primarily a conflict between the Turkish state and Kurdish nationalists, especially those represented by the PKK, and it entails significant regional and

${ }^{14}$ Except for the short-lived Mahabad Republic of Kurdistan in Iran (from January to December 1946). 
socio-economic dimensions (Güneş-Ayata \& Ayata, 2002). Kurds form a heterogeneous group with different levels of integration with the rest of the Turkish society and various levels of ethnic and national self-consciousness. That an estimated half or more of Turkish Kurds live west of Ankara - that is, away from the southeast, where they constitute substantial majorities makes it impractical and unlikely that Turkish Kurds would seek a separate nation-state (Gunter, 2004b).

Kurdish nationalists in Turkey might have already developed a hardened sense of their Kurdishness, whereby Turks play the role of the rival 'other' (Yavuz \& Gunter, 2001). However, for significant portions of Kurds, the Kurdish identity is probably still in the making, in the sense that its socialpolitical significance for individuals and the degree to which Turks are seen as the primary other are still evolving, in response to socio-economic and political influences (Bruinessen, 1998; Kasaba, 2001; Somer, 2004). Accordingly, a long-time scholar of Kurds, Bruinessen (1998: 45) refers to 'potential Kurds': 'besides those who actually speak Kurdish (or Zaza) there are those whose parents do (or one of whose parents does), those with one or more Kurdish grandparents, and those with more distant Kurdish ancestors. Nothing prevents those more peripheral Kurds from discovering and emphasizing their Kurdishness in certain contexts.' One should add that while the increased visibility and politicization of the Kurdish identity might make some potential Kurds accentuate their ethnicity, it might make others who are well-integrated into the mainstream society further suppress their Kurdishness.

Bruinessen's theses are corroborated by the available surveys and estimates on Kurdish identity. Estimates of the total number of Kurds in Turkey, based on mother tongue, range between $12 \%$ and $20 \%$ of the population (Mutlu, 1996; Bruinessen, 1998; Gündüz-Hoşgör \& Smits, 2002). Although surveys on subjective self-identification are insufficient and incommensurate methodologically, their findings are consistent in four senses (Somer, 2004: 249-250). First, subjective self-identification as (fully or partially) Kurdish, which ranges between $9 \%$ and $13 \%$ across surveys conducted at different times, falls short of the estimated total numbers of Kurds. ${ }^{15}$ Second, when given the chance to do so in surveys, significant portions of respondents who selfidentify as Kurds declare multiple identities, identifying with Turkishness and with other identity categories they share with Turks. Third, selfdefinitions vary across time, region, class, and political ideology, as interviews with Kurdish social and political actors also reveal (Çakır, 2004). Fourth, Kurdish ethnicity becomes a major determinant of voting behavior only when it overlaps with both region (the southeast and the east) and socio-economic status (economic deprivation and rural base) (Güneş-Ayata \& Ayata, 2002).

15 See also Başlevent et al. (2004: 314). 


\section{Rival and Compatible Images of Ethnic Categories}

What would determine whether or not those Kurds for whom ethnicity is gaining cognitive and political importance view Turks as the primary, and perhaps also antagonistic, other? A consolidation of the Kurdish identity in the region as a result of Iraqi-Kurdish statehood would have destabilizing effects on Turkey only insofar as Turkish Kurds viewed their bonds with Iraqi Kurds to be their primary identity, and Turks and Kurds came to view each other as opponents.

Identity constructions entail 'boundary rules' that determine who can and cannot be a member, and 'contents' describing which characteristics bond the insiders together and how they relate to outsiders. For example, the particular construction of an identity entails beliefs regarding who can and cannot be a Serb, what the Serbs are like, and, most importantly for the present context, which other groups have an oppositional relationship to Serbs and which groups do not. Thus, it may make Serbs believe that 'Serbs cannot live with Croats, and vice versa' (Fearon \& Laitin, 2000: 848-850).

A simple and flexible post-ethnic analytical categorization capturing these ideas is 'the rival and compatible definitions of identities' (Somer, 2004). The rival definition has two components, an identity component defining two or more identities as mutually exclusive substitutes and an interest component defining the group interests in question as competitive. The rival definition leads actors to make an 'either-or' choice between one or more identity categories, because their competing requirements prevent simultaneous identification. ${ }^{16}$ By contrast, the identity component of the compatible definition characterizes the identities in question as compatible complements, and the associated group interests as positive-sum. Individuals who believe that one can both be Scottish and British, or Kurdish and Turkish, would hold a compatible definition of these categories. These people themselves would not necessarily hold hybrid identities in a post-nationalist sense, but rather believe that it is permissible because simultaneous association with these categories does not require holding contradictory self-conceptions or taking contradictory actions.

Accordingly, the major conflict underlying Turkey's Kurdish question may be viewed as one that takes place between the holders of the rival and compatible definitions of the Turkish and Kurdish identities, not one between Turks and Kurds. Turkey's preventative policies toward Iraqi-Kurdish statehood appear to draw on the assumption that people, especially Turkish Kurds, hold a rival definition of their identities. Insofar as this assumption

16 The situation of ostracized groups such as the Roma constitutes a special case of the rival definition where the choice between two or more categories is not present because 'exit' from one's ascribed group identity is not accepted. 
holds, developments in Iraq can have destabilizing consequences in Turkey by compelling Turkish Kurds, especially those who live in mixed communities with other ethnic groups and who hold conglomerate conceptions of their identities, to make hard choices between the Kurdish and Turkish components of their identities. Simultaneously, increasing portions of the nonKurdish population may begin to view ethnic Kurds antagonistically, which would raise the specter of a Kurdish-Turkish conflict involving large numbers of ordinary individuals, something that has not yet occurred. This could initiate a painful and extensive process of socio-economic and psychological unmixing within integrated communities, which involve large portions of ethnic Kurds living in western Turkey, where they have an enhanced tendency to intermarry with ethnic Turks (Gündüz-Hoşgör \& Smits, 2002). Insofar as the compatible definition prevails, however, Turkey need not fear that the 'pull' of Iraqi Kurds would cause the unmixing of Turkish Kurds from the rest of the Turkish population, because they could nurture multiple identities and a positive-sum perception of their interests with Turks.

The crucial question here is how one can successfully maintain or promote the compatible definition. Anatoly Khazanov (2003: 87) aptly observed in his analysis of Russia's past and present identity crises that 'it is not enough to construct identities. To be successful, these identities have to be accepted.' Studies focusing on the state discourse emphasize that the official discourse plays a crucial role in determining people's identity definitions, along with that of political leaders and mainstream media (Kadığlu, 1997). However, earlier 'conceptual opportunities' for changing the state's discursive and cognitive approach to this conflict were missed; for example, attempts by leaders such as late President Özal to promote a more flexible conceptualization of Turkish national identity proved short-lived and failed to win sufficient sympathy on the ground (Barkey \& Fuller, 1997). Arguably, this occurred because practice is as important as discourse. In order to be credible, the new state discourse had to be supported by complementary policies in the areas of politics, socio-economics, and foreign policy. Part of these policies would have been the adoption of more flexible, differentiated, and democratic rights and practices of citizenship (Keyman \& İçduygu, forthcoming). However, formulating and effectively implementing such policies required substantial state capacity in the sense of both resources and administrative efficiency, which the Turkish state lacked. In addition, any political actor who promoted more flexible definitions of national identity and citizenship faced opposition from hardliners, whose views were based on the assumed prevalence of the rival definition (or who held the rival definition themselves), as well as opportunistic attacks by political rivals. For example, numerous legislative efforts failed to improve the human rights record of the security forces and to trigger economic development in the southeast, at least 
partly because of poor implementation. It will take some time before the significant reforms that have taken place since 1999 in a context of European integration will bear fruit. ${ }^{17}$

One can conjecture a circular relationship between the identity and interest components of identity constructions, as depicted in Figure $1 .{ }^{18}$ The causal mechanism linking identities to perceived interests is collective actions (Hechter \& Okamoto, 2001). People whose dominant discursive-conceptual environments tell them they are mutually exclusive 'others' do not seek joint collective actions. ${ }^{19}$ The less they undertake joint collective actions, the greater their perceptions of difference and the more likely they will perceive their interests to be zero-sum. Alternatively, causality may flow from interest to identity. The more people perceive that they have positive-sum interests, the more they seek joint collective actions, thereby tending to develop compatible definitions of their identities.

The simple circular relationship depicted in Figure 1 can be broken whenever collective actions are not available in the direction in which the content of an identity is evolving. Opportunity structures for collective actions determine whether reinforcing (positive) or negative feedbacks prevail after each step. Imagine that powerful actors are discursively promoting the compatible definition between two ethnic groups. This would also trigger negative feedback by inciting hardliner political entrepreneurs on both sides to fight back through increasing their efforts to promote the rival definition. If the proponents of the compatible definition fail to organize joint collective actions pursuing positive-sum interests, the compatible definition will fail to gain credibility. Here, state capacity to create opportunities for such collective actions is crucial. In this sense, a major weakness of the Turkish state was its failure to create opportunities for the emergence of moderate political movements that represented the Kurdish identity and had mixed membership by clamping down on moderate Kurdish political actors along with hardline Kurdish nationalists. Expectedly, post-1999 liberalization has allowed the emergence of moderate Kurdish voices inside and outside the PKK, which, threatened by such developments, has intensified its efforts to oppress these voices and ended a self-declared ceasefire vis-à-vis the Turkish government in June 2004. ${ }^{20}$

\footnotetext{
${ }^{17}$ For a comprehensive discussion of the concept of state capacity, see Migdal (2001). For an analysis of Turkey's reform efforts in the context of EU relations, see Öniş (2004).

${ }^{18}$ It is not argued here that identities are responsive to the processes of remaking summarized in Figure 1 to the same degree at all times. These processes will be especially effective in periods of flux and uncertainty, when people feel insecure and uncertain about their identities and when major political-institutional changes are expected. See also Laitin (1998) and Somer (2004).

19 The determination of the dominant (equilibrium) discursive environment through social and political processes, whereby political entrepreneurs play major roles, requires separate treatment. For a detailed discussion and explanation, see Somer $(2001,2002)$

${ }^{20}$ The Economist (2004).
} 


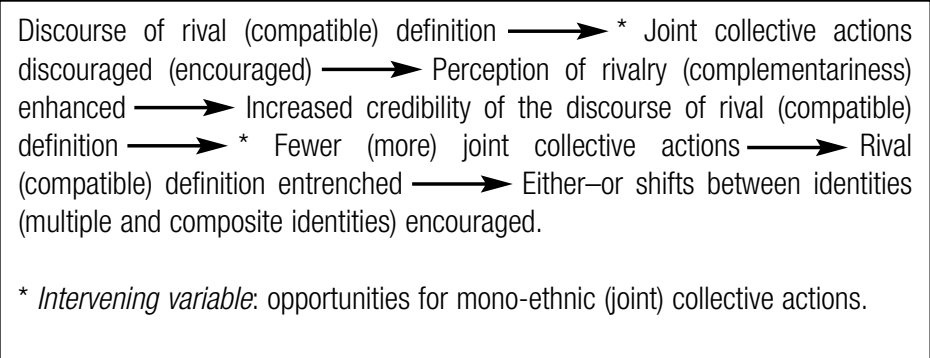

Figure 1. The Making of Oppositional and Harmonious Identities

Figure 2 describes the argument that successfully promoting a compatible definition requires that both the state discourse and policies are consistent with the compatible definition, as the bottom right box indicates. ${ }^{21}$ The top right box implies that compatible policies would fail unless combined with a parallel discourse. This is because the rivalry discourse would undermine the credibility of these policies by suggesting that they do not reflect the state's long-term strategies.

\begin{tabular}{cc|c|c|}
\multicolumn{1}{c}{} & \multicolumn{2}{c}{ ACTUAL POLICIES } \\
\multicolumn{1}{c}{ Rival definition } & \multicolumn{1}{c|}{ Compatible definition } \\
\cline { 3 - 4 } STATE & Rival definition & $\begin{array}{c}\text { Perception of rival } \\
\text { definition }\end{array}$ & $\begin{array}{c}\text { Perception of rival } \\
\text { definition }\end{array}$ \\
\cline { 3 - 4 } & Compatible definition & $\begin{array}{c}\text { Perception of rival } \\
\text { definition }\end{array}$ & $\begin{array}{c}\text { Perception of } \\
\text { compatible definition }\end{array}$ \\
\cline { 3 - 4 } & &
\end{tabular}

Figure 2. Credibility of State Discourse

Policies promoting the compatible definition include the creation of opportunities for collective actions expressing the compatible definition; developmental policies generating positive-sum interests in the integration of the ethnic group members with the rest of the national economy; the creation by state institutions of inclusive conditions for ethnic group members and the promotion of respect for their identities; and actions that ensure that ethnic group members perceive the state to be acting in such a manner. Thus, the

21 The assumed initial conditions in this analysis are that there is imperfect integration between the two groups and the rival definition prevails at least among some segments of the population. In a hypothetical society that is highly integrated and where the compatible definition prevails, the promotion of the rival definition would face similar difficulties and the rival definition would be the outcome only in the top right box of the matrix. 
GROUP A EXPRESSING

Rival definition Compatible definition

GROUP B

EXPRESSING

\begin{tabular}{|c|c|c|}
\hline & \multicolumn{2}{|c|}{ GROUP A EXPRESSING } \\
\hline & Rival definition & Compatible definition \\
\hline Rival definition & Rival definition & Rival definition \\
\hline Compatible definition & Rival definition & Compatible definition \\
\hline
\end{tabular}

Figure 3. The Compatible Definition as Focal Point

legal framework regarding ethnic-linguistic rights, as well as consistent implementation of these rights, is crucial.

Internationally, a state discourse emphasizing the compatibility of group interests coupled with benevolent policies can make members of an ethnic other embrace the compatible definition. In the case of Turkey and Iraq, this would imply a state discourse promoting the compatible definition coupled with actual policies de-emphasizing security concerns and emphasizing humanitarian and political-economic cooperation with Iraqi Kurds.

To sum up the theoretical discussion here, the ethnicity discourse - that is, one that emphasizes actors' ethnicity in describing them and analyzing their behavior - undermines cooperation only insofar as it takes the form of the rival definition or is perceived as so doing. However, the ethnicity discourse has a propensity to be perceived in terms of the rival definition for the following reasons. First, successful promotion of the compatible definition requires combination with credible policies on the ground, which may be costly and hard to implement concurrently. Second, the compatible definition requires coordination between two (or more) groups: it fails unless substantial portions of these groups embrace it openly.22 This point is illustrated in Figure 3. The compatible definition involves the claim that two or more groups can be mutually inclusive and have positive-sum interests. As soon as one of the groups (i.e. substantial portions of it) reveals its adherence to exclusiveness or zero-sum interests, the compatible definition's claim is discredited. Thus, the compatible definition as the dominant belief structure is a fragile outcome. It can last via, among other factors, socio-economic integration that is sufficient to create high levels of trust between the members of the groups (Somer, 2002).

22 Thus, the compatible definition has some of the characteristics of focal points or 'equilibrium beliefs'. 


\section{Implications for Iraq}

Poverty, instability, and repressed ambitions of autonomy or statehood may lead Iraqi-Kurdish leaders to capitalize on nationalism and pursue antagonistic policies toward neighboring countries in order to deflect popular resentment and remain in power. Similarly, new, Saddam-like authoritarian regimes may pursue hostile policies toward democratic Turkey. In addition to strengthening the rival definition inside Turkey, this would weaken Turkey's chances of EU membership, because the Union may try to avoid facing a hostile neighbor at what would be its southeastern border. By comparison, Iraqi Kurds whose ambitions of statehood have been met by a stable political configuration that at least maintains their gains since 1991 would be eager to maintain good relations with a large neighbor at the doorstep of the EU.

Accordingly, from a dispassionate perspective, it appears that Turkey's primary interests lie in, first, Iraq's economic and political stability; second, the emergence of a democratic regime in Iraq; and, third, the pursuit of friendly and cooperative relations with Turkey by the new Iraqi administration in general - and by Iraqi Kurds in particular. In fact, this outcome should probably be the overriding strategic objective for Turkey, as well as for the USA, the EU, and Iraqi Kurds.

For its own reasons, Turkey might not favor an ethnic federation in Iraq, a position that has also been taken by many Iraqis and independent observers (Makiya, 2003). ${ }^{23}$ Ethnicity-based federations institutionalize - and indirectly promote - ethnic divisions, and create minorities within minorities. A Kurdcontrolled state in a federal Iraq would create discontented Turkmen and Arab minorities. As other examples in the world have shown, if such discontent turns into a breakdown of inter-ethnic trust, this can lead to rapid and violent unmixing in ethnically integrated areas (Somer, 2002). In Iraq, recent developments have already caused tensions and violence in mixed areas such as the oil-rich city of Kirkuk, which is simultaneously claimed by Arabs, Kurds, and Turkmen. While it may be desirable to reverse the effects of the earlier forced Arabization policies by allowing internally displaced Kurds, Turkmen, and others to return to the city, a major challenge is how to accomplish this without creating new injustices and forms of ethnic domination. ${ }^{24}$ The deterioration of Kurdish-Turkmen and Kurdish-Arab relations would have negative ramifications for Kurds' relations with Turkey and other neighboring countries, and undermine the compatible definition of Turkish-Kurdish relations in Turkey. Thus, Turkey may choose to support a democratic federation, whereby consociational practices protect the cultural

\footnotetext{
${ }^{23}$ For a counterview, see Gunter (2003).

${ }^{24}$ For example, Human Rights Watch (2004: 46-55), Turkish Daily News (2004).
} 
and political-economic interests of all ethnic-religious groups, perhaps with special privileges for the Kurds in northern Iraq. In other words, a solution may be possible that lies between ethnic federation and a democraticmajoritarian federation oblivious to ethnic-religious divisions. Because Iraq lacks a dominant ethnic-religious group or 'Staatsvolk', such a mixed solution may be necessary ( $\mathrm{O}^{\prime}$ Leary, 2003).

However, the aversion to ethnic federation on the part of Turkey and other regional actors appears to be less important than ensuring that post-Saddam Iraq will have friendly relations with Turkey, whatever its political configuration. An ethnicity-based state in northern Iraq may or may not have cooperative relations with Turkey. By comparison, any administration that is unstable and perceives that it has rival interests with Turkey would almost automatically induce hostile ethnic nationalism on both sides.

Kurdish statehood is unlikely, because regional countries such as Turkey, Iran, and Syria, on which Iraqi Kurds are economically dependent, strongly oppose it. Talk of Kurdish statehood has drawn Turkey and these countries closer to each other. ${ }^{25}$ Kurdish independence would require internationally recognized secession (from Iraq), which has been a rare phenomenon in the post-World War II era, except for the processes of decolonization and the collapse of the Soviet bloc. Any Kurdish 'right' to secede, based on notions of self-determination, is highly debatable on philosophical or practical grounds (Horowitz, 2003). The fact that Turkey has a longstanding alliance with the USA also provides means to affect the US position toward Kurdish independence.

Insofar as the possibility and negative ramifications for Turkey of Kurdish statehood are limited, elevating its prevention to Turkey's primary strategic objective gives the false impression that Turkish and Kurdish interests are in fundamental conflict, and serves to promote the rival definition. The rival definition is likely to alienate Turkish Kurds and increase Turkish-Kurdish and Kurdish-Turkmen polarization, with the likely results of undermining Turkey's democratization and EU integration. Because the rival definition compels Turkish Kurds to make either-or choices between their ethnic and national identities, it may also increase intra-Kurdish conflicts.

For their own part, Iraqi-Kurdish leaders have neither been able to focus on long-term goals nor to avoid the rival definition. They appear to fear foremost that Turkey has concealed 'imperialist' intentions in the region, and that they will be betrayed by the USA. It is true that Kurds have been let down by the USA before, and they have historically been subjected to divideand-rule policies from their Ottoman, Turkish, Persian, Arab, or British overlords. Simultaneously, the Kurdish leadership has a record of shifting loyalties, which regional countries have both distrusted and exploited. Thus,

${ }^{25}$ New York Times, 2004. 
trust is lacking between the Turkish government and the Kurdish leadership. Simultaneously, cooperation between Turkey and Iraqi Kurds during the 1990s entailed Turkey's active assistance in the development of the economy and the Kurdish administration in the no-flight zone that was established in the wake of the 1991-92 war on Iraq. Iraqi Kurds clearly prefer an ethnicitybased federal Iraq in which Kurds would be in control of northern Iraq, and this constitutes a major conflict of interest with Turkey. Again, however, this should be a less important issue than friendly and cooperative relations with neighboring countries, which Iraqi Kurds need for their security and economic survival. In this sense, the interests of moderate Iraqi Kurds may conflict with those of pan-Kurdish nationalists, who may seek unification with the Kurdish-populated regions of Iran, Turkey, and Syria.

Important long-term policies that would contribute to the creation of positive-sum interests in Turkey's relations with Iraqi Kurds have so far received inadequate attention, even on the conceptual level. Such policies include the creation of economic-political interdependency by fostering mutually beneficial trade and investment relationships between Turkey and Iraq, which would help to reduce lack of trust and encourage constructive policies on both sides. Alongside humanitarian aid, Turkey can increase its efforts to contribute to the postwar economic and democratic development of northern Iraq, in cooperation with the USA and the EU. Turkish-US talks might include projects to let Turkey use part of the US compensation for the war on Iraq toward mutually beneficial developmental projects in northern Iraq.

In the military realm, Turkey's contributing to the training of Iraqi security forces, including that of Iraqi Kurds, would be more conducive to the development of long-term trust and cooperation between Turkey and Iraq than any deployment of Turkish troops on Iraqi soil. While the establishment of order and security is an obvious priority in Iraq now, long-term security depends on ensuring economic cooperation and development among neighboring countries.

* Murat Somer is Assistant Professor of International Relations, Koç University, Istanbul. E-mail: musomer@ku.edu.tr. The author would like to thank the audience and panelists at the 2003 Middle East \& Central Asia Politics, Economics, and Society Conference, University of Utah, Salt Lake City, 16-18 October 2003, and the anonymous referees of this article for their comments and criticisms, as well as Koray Mutlu for research assistance. 


\section{References}

American Political Science Review, 2000. 'Analytical Narratives by Bates, Greif, Levi, Rosenthal, and Weingast: A Review and Response', American Political Science Review 94(3): 685-702.

Barkey, Henri, 2000. 'Hemmed in by Circumstances: Turkey and Iraq since the Gulf War', Middle East Policy 12(4): 110-126.

Barkey, Henri J. \& Graham E. Fuller, 1997. ‘Turkey's Kurdish Question: Critical Turning Points and Missed Opportunities', Middle East Journal 51(1): 59-79.

Başlevent, Cem; Hasan Kirmanoğlu \& Burhan Şenatalar, 2004. 'Voter Profiles and Fragmentation in the Turkish Party System', Party Politics 10(3): 307-324.

Bates, Robert H.; Avner Greif, Margaret Levi, Jean-Laurent Rosenthal \& Barry R. Weingast, 1998. Analytic Narratives. Princeton, NJ: Princeton University Press.

Birand, Mehmet A., 2003. 'Turkish and Iraqi Kurds Have Been Divided', Turkish Daily News (Istanbul), March 14; available at http://www.turkishdailynews.com/old_editions/03_14_03/birand.htm (accessed 7 September 2004).

Brubaker, Rogers, 1996. Nationalism Refrained: Nationhood and the National Question in the New Europe. Cambridge: Cambridge University Press.

Bruinessen, Martin van, 1998. 'Shifting National and Ethnic Identities: The Kurds in Turkey and the European Diaspora', Journal of Muslim Minority Affairs 18(1): 39-52.

Çakır, Ruşen, ed., 2004. Türkiye'nin Kürt Sorunu [Turkey's Kurdish Problem]. Istanbul: Metis Yayınları.

Çandar, Cengiz, 2004. 'Turkish Foreign Policy and the War On Iraq', in Lenore G. Martin \& Dimitris Keridis, eds, The Future of Turkish Foreign Policy. London: MIT Press (37-60).

Demirelli, Fatma, 2003. 'Gul Assures Ambassadors on Turkey's Iraq Motives', Turkish Daily News (Istanbul), October 10; available at http:/ /www.turkishdailynews.com/ old_editions/10_10_03/for.htm\#f9 (accessed 7 September 2004).

Economist, The (London), 2004. 'A Kurd on the Rise', 4-10 September.

Ergan, Uğur, 2003. 'Türkiye Kürtlere Karşı Daha Esnek, Daha Samimi' [Turkey More Flexible and Sincere Toward Kurds], Hürriyet (İstanbul), June 5; available at http:/ / www.hurriyetim.com.tr/haber/0,,sid 7@tarih 2003-06-05-m@nvid 275817,00.asp (accessed 7 September 2004).

Fearon, James D. \& David D. Laitin, 2000. 'Violence and the Social Construction of Ethnic Identity', International Organization 54(4): 845-877.

Goldstein, Judith and Robert O. Keohane, 1993. 'Ideas and Foreign Policy: An Analytical Framework', in Judith Goldstein and Robert O. Keohane, eds, Ideas and Foreign Policy, Beliefs. Institutions, and Political Change. Ithaca: Cornell University Press.

Gorvett, Jon, 2003. 'Turkish Chief of Staff Says Ankara Has No "Hidden Designs" on Northern Iraqi Kurds', Washington Report on Middle East Affairs, May: 36-37.

Gündüz-Hoşgör, Ayşe \& Jeroen Smits, 2002. 'Intermariage Between Turks and Kurds in Contemporary Turkey: Interethnic Relations in an Urbanizing Environment', European Sociological Review 18(4): 417-432.

Güneş-Ayata, Ayşe \& Sencer Ayata, 2002. 'Ethnic and Religious Bases of Voting', in Sabri Sayarı \& Yılmaz Esmer, eds, Politics, Parties, and Elections in Turkey. Boulder, CO: Lynne Rienner (137-155).

Gunter, Michael M., 2003. 'Kurdish Future in a Post-Saddam Iraq', Journal of Muslim Minority Affairs 23(1): 9-23.

Gunter, Michael M., 2004a. 'The Kurdish Question in Perspective', World Affairs 166(4): 197-205. 
Gunter, Michael M., 2004b. 'Why Kurdish Statehood Is Unlikely', Middle East Policy 11(1): 106-110.

Hechter, Michael \& Dina Okamoto, 2001. 'Political Consequences of Minority Group Formation', Annual Review of Political Science 4(1): 189-215.

Horowitz, Donald L., 2003. 'The Cracked Foundations of the Right To Secede', Journal of Democracy 14(2): 5-17.

Human Rights Watch, 2004. Claims in Ethnic Conflict:Reversing Ethnic Cleansing in Northern Iraq. August 2004, vol. 16, No. 4(E).

Kadıoglu, Ayşe, 1997. 'The Paradox of Turkish Nationalism and the Construction of Official Identity', Middle Eastern Studies 32(2): 177-193.

Kalyvas, Stathis N., 2003. "The Ontology of "Political Violence": Action and Identity in Civil Wars', Perspectives on Politics 1(3): 475-494.

Kasaba, Reşat, 2001. 'Kurds in Turkey: A Nationalist Movement in the Making', in Daniel Chirot \& Martin E. P. Seligman, eds, Ethnopolitical Warfare: Causes, Consequences, and Possible Solutions. Washington, DC: American Psychological Association (163-177).

Keating, Michael, 2004, 'European Integration and the Nationalities Question', Politics $\mathcal{E}$ Society 31(3): 367-388.

Keyman, Fuat E. \& Ahmet İçduygu, forthcoming. 'Introduction: Citizenship, Identity, and the Question of Democracy in Turkey', in E. Fuat Keyman \& Ahmet Içcuygu, eds, Citizenship in A Global World. London: Routledge (1-27).

Khazanov, Anatoly M., 2003. 'A State Without a Nation? Russia After Empire', in T. V. Paul, G. John Ikenberry \& John A. Hall, eds, The Nation-State in Question. Princeton, NJ: Princeton University Press (79-105).

Kirişçi, Kemal, 2004. 'The Kurdish Question and Turkish Foreign Policy', in Lenore G. Martin \& Dimitris Keridis, eds, The Future of Turkish Foreign Policy. London: MIT Press (277-314).

Kuusisto, Riikka, 1998. 'Framing the Wars in the Gulf and in Bosnia: The Rhetorical Definitions of the Western Power Leaders in Action', Journal of Peace Research 35(5): 603-620.

Laitin, David D., 1998. Identity in Formation: The Russian-Speaking Populations in the Near Abroad. Ithaca, NY: Cornell University Press.

Makiya, Kanan, 2003. 'A Model for Post-Saddam Iraq', Journal of Democracy 14(3): 5-12.

Migdal, Joel S., 2001. State in Society: Studying How States and Societies Transform and Constitute One Another. New York: Cambridge University Press.

Mutlu, Servet, 1996. 'Ethnic Kurds in Turkey: A Demographic Study', International Journal of Middle East Studies 28(4): 517-541.

Natali, Denise, 2004. 'Transnational Networks: New Opportunities and Constraints for Kurdish Statehood', Middle East Policy 11(1): 111-114.

New York Times, 2004. 'Syria, Turkey Insist Iraq Remain United', 6 January; available at http:/ / www.nytimes.com (accessed 7 January 2004).

O'Leary, Brendan, 2003. 'What States Can Do With Nations: An Iron Law of Nationalism and Federation?', in T. V. Paul, G. John Ikenberry \& John A. Hall, eds, The Nation-State in Question. Princeton, NJ: Princeton University Press (51-78).

Öniş, Ziya, 2004. 'Diverse but Converging Paths to European Union Membership: Poland and Turkey in Comparative Perspective', East European Politics and Societies 18(3): 481-512.

Özkan, Tuncay, 2004. CIA Kürtleri [CIA Kurds]. İstanbul: Alfa Yayınları.

Robins, Philip, 2003. 'Confusion at Home, Confusion Abroad: Turkey Between Copenhagen and Iraq', International Affairs 79(3): 547-566.

Ruggie, John G., 1998. Constructing the World Polity: Essays on International Institutionalization. New York: Routledge. 
Salih, Khaled, 2004. 'Kurdish Reality in an Emerging Iraq', Middle East Policy 11(1): 122-126.

Schmitt, Eric, 2003. 'Turkey Seems Set To Let 60,000 GI's Use Bases for War', New York Times, 26 February; available at http:/ / www.nytimes.com (accessed 8 December 2003).

Somer, Murat, 2001. 'Cascades of Ethnic Polarization: Lessons from Yugoslavia', Annals of the American Academy of Political and Social Science 573 (January): 127-151.

Somer, Murat, 2002. 'Insincere Public Discourse, Trust, and Implications for Democratic Transition: The Yugoslav Meltdown Revisited', Journal for Institutional Innovation, Development, and Transition 6(1): 92-112.

Somer, Murat, 2004. 'Turkey's Kurdish Conflict: Changing Context and Domestic and Regional Implications', Middle East Journal 58(2): 235-253.

Turkish Daily News (Istanbul), 2003a. 'Thousands of Kurds March Against Turkey', 4 March; available at http://www.turkishdailynews.com/old_editions/03_04_03/for. htm\#f7 (accessed 7 September 2004).

Turkish Daily News (Istanbul), 2003b. 'Turkey Says It Won't Send Troops to Iraq If Unwanted', 20 October; available at http://www.turkishdailynews.com/old_editions/10_20_03/for.htm\#f5 (accessed 7 September 2004).

Turkish Daily News (Istanbul), 2003c. 'Ankara Signals Iraq Concern After Troop Plans Dropped', 10 November; available at http://www.turkishdailynews.com/old_ editions/11_10_03/for.htm\#f7 (accessed 8 December 2003).

Turkish Daily News (Istanbul), 2004. 'Tension Runs High in Kirkuk', 3 January; available at http:/ / www.turkishdailynews.com/old_editions/01_03_04/for.htm\#f7 (accessed 7 September 2004).

Yavuz, Hakan \& Michael M. Gunter, 2001. 'The Kurdish Nation', Current History 100(642): 33-39.

Yetkin, Murat, 2004. Tezkere: Irak Krizinin Gerçek Öyküsü [The Motion: The Real Story of the Iraq Crisis]. Istanbul: Remzi Kitabevi. 